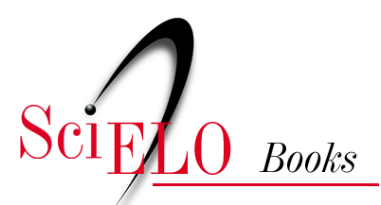

\title{
20. Os Construtores da Moderna Medicina
}

\author{
Joffre Marcondes de Rezende
}

\section{SciELO Books / SciELO Livros / SciELO Libros}

REZENDE, J. M. Os Construtores da Moderna Medicina. In: À sombra do plátano: crônicas de história da medicina [online]. São Paulo: Editora Unifesp, 2009, pp. 181-200. História da Medicina series, vol. 2. ISBN 978-85-61673-63-5. https://doi.org/10.7476/9788561673635.0021.

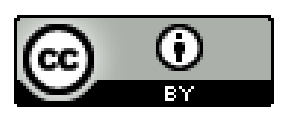

All the contents of this work, except where otherwise noted, is licensed under a Creative Commons Attribution 4.0 International license.

Todo o conteúdo deste trabalho, exceto quando houver ressalva, é publicado sob a licença Creative Commons Atribição 4.0.

Todo el contenido de esta obra, excepto donde se indique lo contrario, está bajo licencia de la licencia Creative Commons Reconocimento 4.0. 


\section{Os Construtores da Moderna Medicina*}

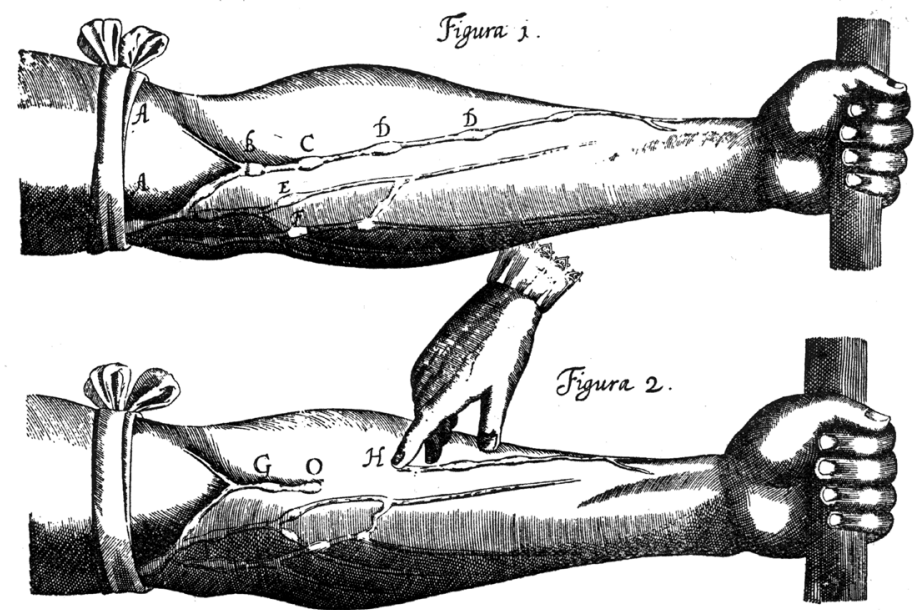

Ilustração do livro Estudo Anatômico do Movimento do Coração e do Sangue nos Animais, de William Harvey.

R ecentemente foi publicado um livro sob o título As Dez Maiores Descobertas da Medicina. Seus autores, Meyer Friedman e Gerald Friedland, admitem que a seleção foi feita baseada em critérios subjetivos e que cada historiador poderia organizar sua própria lista, diferente da que foi apresentada.

Preferimos comparar a moderna medicina a uma grande construção, edificada durante séculos, e nos perguntamos, o que é mais importante em um edifício solidamente construído: as fundações, as pilastras de sustentação, ou o acabamento e a decoração? Concluímos que são as fundações e as pilastras.

Com essa visão, em lugar de dez, selecionamos vinte personagens da História da Medicina que, a nosso ver, forneceram as bases e contribuíram de maneira decisiva para a construção da moderna medicina: dois são da

* Apresentado ao xv Encontro Científico dos Acadêmicos de Medicina. Goiânia, I 8 de setembro de 2003. 
Antiguidade, um do século XVI, um do século XVII, três do século XVIII, sete do século XIX e seis do século Xx.

\section{Antiguidade}

Hipócrates (460-355 a.C.)

Colocamos em primeiro lugar Hipócrates e sua escola, marco inicial da medicina racional. Hipócrates separou a medicina da religião e da magia, bem como da filosofia especulativa, e afastou a ideia de causas sobrenaturais para as doenças, interpretando estas como fenômenos naturais resultantes da condição biológica do homem e de sua interação com o meio ambiente. Ressaltou a importância da observação clínica para o diagnóstico e o prognóstico e estabeleceu normas para a anamnese e o exame físico do paciente. Com base unicamente na observação clínica descreveu várias doenças e condições patológicas diversas. A par disso, deu dignidade à profissão médica, elaborando os preceitos éticos fundamentais indispensáveis ao exercício da medicina (Castiglioni, I947, pp. I74-2 I I).

$$
\text { Galeno (I30-200) }
$$

Cinco séculos separam Hipócrates de Galeno. Claudius Galenus era um médico grego que viveu a maior parte de sua vida em Roma, onde desenvolveu intensa atividade, exercendo a clínica, fazendo dissecções e experimentos em animais e escrevendo sem cessar. Calcula-se que tenha escrito cerca de quatrocentos livros sobre vários assuntos, setenta dos quais sobre medicina. Parte de seus manuscritos se perdeu em um incêndio no Templo da Paz, em Roma, onde os mesmos se encontravam. Galeno era monoteísta e considerava o corpo apenas como instrumento da alma, ensinamento que lhe valeu o apoio da Igreja. Sua obra foi considerada definitiva para o ensino e a prática da medicina e perdurou como tal até a Idade Média, ou seja por I 300 anos. Somente no Renascimento todo o sistema de Galeno começou a ser questionado. Apesar dos muitos erros que cometeu, sua contribuição mais relevante diz respeito à anatomia e à fisiologia. Deve-se a ele o importante princípio de que qualquer alteração da função corresponde a uma lesão e vice-versa (Idem, pp. 256-266). 
Vesalius ( I 5 I 4-I 564)

Andreas Vesalius era belga de nascimento, natural de Bruxelas; estudou em Louvain e Paris e ensinou anatomia na Universidade de Pádua, na Itália, na época a mais importante escola médica da Europa. Com base na dissecção de cadáveres, demonstrou todos os erros de anatomia cometidos por Galeno, que se baseava na dissecção de animais, uma vez que era proibida a dissecção de corpos humanos no Império Romano. Aos 29 anos de idade publicou sua monumental obra intitulada De bumanis corporis fabrica ( $A$ Estrutura do Corpo Humano), que lhe deu um lugar de destaque na História da Medicina e lhe valeu a ira dos seus contemporâneos, os quais não aceitavam que Galeno houvesse errado.

Vesalius dissecava pessoalmente os cadáveres, o que não era costume entre os professsores de anatomia, que permaneciam sentados em uma espécie de púlpito (cátedra), de onde assistiam a dissecção feita por auxiliares, geralmente cirurgiões-barbeiros, e comentavam o que se encontrava nos livros de Galeno. Em uma das sessões públicas de dissecção, Vesalius foi advertido de que uma de suas afirmações estava em desacordo com Galeno, ao que ele replicou que, nesse caso, o erro era de Galeno. Os professores presentes retiraram-se da sala em protesto contra a arrogância desse jovem pretensioso (Tarchis, I950, pp. I8-78).

\section{Século XVII}

Harvey (I 578-I657)

William Harvey era natural da Inglaterra, estudou medicina em Pádua, na Itália, e regressou ao seu país, onde realizou a maior descoberta do século, que foi a da circulação do sangue. Até então prevalecia o modelo proposto por Galeno para a irrigação sanguínea dos órgãos, segundo o qual o sangue difundia-se a todo o corpo pelas veias, regressando ao coração pela mesma via. As artérias se destinavam a conduzir o ar dos pulmões, de mistura com uma menor quantidade de sangue que passava do ventrículo direito ao 
esquerdo através de poros existentes no septo interventricular. Tais poros, na verdade, não existiam, como provou Vesalius.

Por meio da vivissecção nas mais diferentes espécies animais verificou Harvey que o coração se contrai durante a sístole, expulsando o sangue dos ventrículos em direção à aorta e à artéria pulmonar e dilata-se durante a diástole, recebendo o sangue da veia cava e da veia pulmonar. Calculou a quantidade de sangue ejetada em cada sístole e concluiu matematicamente que a movimentação ininterrupta de tão grande quantidade de sangue só seria possível se o sangue circulasse através das artérias até os tecidos e retornasse pelas veias ao coração. Como os capilares ainda eram desconhecidos, Harvey admitiu a existência de anastomoses arteriovenosas ou simplesmente a passagem do sangue através de porosidades nos tecidos.

Harvey foi o primeiro a empregar cálculos matemáticos na avaliação de um fenômeno biológico. Foi tão revolucionária a sua descoberta que o próprio Harvey previu a reação dos seus contemporâneos, expressa na seguinte frase: "o que vou dizer parecerá tão novo e inédito que tenho receio de me expor não somente à inveja maldosa de algumas pessoas mas também à inimizade de todos os homens" (Harvey, 2009, p. 246).

\section{Século XVIII}

\section{Morgagni (I682-I77I)}

Giovanni Battista Morgagni foi o fundador da anatomia patológica. Foi professor de anatomia na Universidade de Pádua durante 56 anos. Em I76I, aos setenta anos, publicou sua monumental obra em cinco volumes De Sedibus et Causis Morborum (Da Sede e Causas das Doenças), fruto de seus estudos e observações em autópsias por ele realizadas ou orientadas.

Procurou correlacionar os sintomas apresentados em vida pelos enfermos com as lesões anatômicas encontradas nos diferentes órgãos. Dentre os seus relatos mais importantes cumpre destacar os de aneurisma sifilítico da aorta, atrofia amarela aguda do fígado, meningite secundária à otite, câncer do estômago, úlcera gástrica, colelitíase, endocardite, estenose mitral, insuficiência aórtica, estenose pulmonar, esclerose das coronárias, tetralogia de Fallot, coarctação da aorta e ileíte regional. 
Os seus contemporâneos não alcançaram o verdadeiro significado de sua obra, uma das principais fundações da medicina moderna (Long, I965 b, pp. 63-75).

\section{Lavoisier (I743-I794)}

Antoine Laurent Lavoisier nasceu em Paris, em I743, descendente de família abastada, tendo recebido instrução aprimorada e estudado química, botânica, matemática e astronomia. Além de outras atividades que exercia, dedicou-se desde cedo à pesquisa científica, tendo para isso montado o seu próprio laboratório. Aos 25 anos foi admitido como membro associado da Academia de Ciências da França. Casou-se com uma jovem de nome Marie Anne Paulze, que se tornou, além de esposa, sua assistente e secretária, fazendo anotações de suas experiências e colaborando com ilustrações para os seus livros.

É consenso entre cientistas e historiadores de que a química moderna nasceu com Lavoisier. Dentre suas muitas contribuições, a maior de todas, que trouxe prodigioso avanço à medicina, foi a identificação do "ar vital" ou "ar do fogo", necessário à vida e à combustão, a que deu o nome de oxigênio (do grego oksy, ácido + génos, origem) e de seu papel na respiração e na produção do calor animal.

Estudando o mecanismo da combustão, Lavoisier demonstrou o erro da teoria flogística então vigente. Segundo esta teoria os corpos conteriam uma substância, o "flogisto", que se desprendia pela queima, gerando calor. O "calor inato" dos animais seria resultante do desprendimento do flogisto contido nos alimentos ingeridos. Verificou Lavoisier que os corpos quando se queimam ou se oxidam absorvem oxigênio e teve a intuição de que o calor animal nada mais era que uma combustão interna, na qual seria consumido oxigênio do ar inspirado e desprendido o gás carbônico.Comparou a produção do calor animal à queima do carvão, em que há consumo de oxigênio e produção de gás carbônico e água.

Esta hipótese foi comprovada por Laplace, matemático e amigo de Lavoisier, comparando a quantidade de gás carbônico eliminado com o calor produzido por um animal, e também assim procedendo em relação à queima de certa quantidade de carvão. Concluiu Laplace que o calor produzido, tanto num como noutro caso, é proporcional ao consumo de oxigênio. 
Lavoisier, considerado um dos maiores gênios da humanidade, foi condenado à morte pela Revolução Francesa de $\mathrm{I} 789$, por suas ligações com a realeza, tendo sido guilhotinado em 8 de maio de I794, quando contava 5I anos (Porter, 1995, pp. 4I4-4I 5).

$$
\text { Jenner (I 749-I 823) }
$$

Edward Jenner, modesto médico que clinicava em Berkeley, pequena cidade da Inglaterra, realizou uma das maiores descobertas científicas da medicina - a vacina antivariólica. Jenner, já aos treze anos, manifestara desejo de ser médico; transferiu-se para a cidade de Sodbury, onde Ludlow, famoso cirurgião na época, o recebeu como aprendiz. Aos 2 I anos mudou-se para Londres para estudar e praticar com John Hunter, de quem se tornou discípulo dileto e com quem manteve amizade e trocou correspondência até a morte de seu mestre. Após três anos em Londres decidiu voltar para Berkeley, onde iniciou o seu trabalho como médico geral.

A convivência com Hunter havia aguçado nele inata tendência à observação e investigação cuidadosa dos fatos. Jenner lembrava-se de ter ouvido de uma paciente em Sodbury que estava livre da varíola por haver sido contaminada antes com a varíola da vaca (cowpox). Em Berkeley esta crença era difundida e Jenner durante anos de acompanhamento de pessoas que haviam tido a varíola da vaca verificou que nenhuma delas apresentou varíola durante os surtos epidêmicos da doença.

Convencido de que o "vírus" da varíola bovina imunizava a pessoa para a varíola humana, realizou em I 796 sua experência crucial: inoculou no braço de um menino de oito anos materal colhido em uma pústula da mão de uma pessoa infectada pela varíola bovina. A criança apresentou reação eritêmato-pustulosa no local da escarificação e escassos sintomas gerais. Decorridas 6 semanas Jenner inoculou o pus da varíola humana na criança, com resultado negativo. Estava descoberta a vacina antivariólica!

Somente em 1798 publicou por conta própria o seu trabalho, visto que a Royal Society não o aceitou (Major, I954, pp. 606-609). 


\section{Século XIX}

\section{Schwann ( I 8 IO-I 882 )}

Theodor Schwann, anatomista alemão, foi professor de anatomia e fisiologia em Berlim, Louvain e Liège. Influenciado pelo botânico Matthias Schleiden, que havia descrito a estrutura celular das plantas, demonstrou, em I 83 8, que os animais tinham estrutura semelhante. Embora reconhecendo a importância do núcleo, tanto Schleiden como Schwann não perceberam o processo de divisão celular. Schwann admitiu que novas células poderiam formar-se a partir do material intercelular, a que chamou de "citoblastema". A descoberta da estrutura celular dos animais abriu caminho para a patologia celular de Virchow.

Schwann foi um grande pesquisador: descreveu a bainha de mielina dos nervos ou neurilema, conhecida pelo epônimo de bainha de Schwann; descobriu a pepsina em I 835 , e demonstrou experimentalmente que a bile é essencial à digestão (Porter, op. cit., pp. 4I4-4I5).

\section{Virchow (I82I-I902)}

Rudolf Virchow, patologista alemão, recebeu o grau de médico aos 22 anos de idade e aos 26 já era livre-docente e fundou a revista Virchow Archiv, um dos mais consagrados periódicos médicos até os dias de hoje. Dotado de inteligência privilegiada e determinação foi, a um só tempo, professor de anatomia patológica, pesquisador, sanitarista, político, antropólogo, historiador e editor da revista por ele fundada. Foi diretor do Instituto Patológico de Berlim por mais de quarenta anos. Publicou inúmeros trabalhos originais, dentre os quais cumpre destacar seus estudos sobre tromboembolismo e endocardite.

Sua obra máxima, que o imortalizou, foi o livro Celular Pathologie, publicado em I 858 . Neste livro desenvolveu a tese de que a célula é a unidade fundamental dos seres vivos e que cada célula provém de outra célula da mesma linhagem, seja ela normal ou patológica. As doenças orgânicas indicam lesões patológicas devidas a alterações celulares e não humorais, como se acreditava. O conceito de patologia celular causou verdadeira revolução 
no pensamento médico e sepultou de vez a teoria dos quatro humores que orientou a prática médica por mais de dois mil anos.

Além dessa obra magna escreveu um tratado sobre tumores, no qual descreveu, classificou e deu nome a diversos tipos de tumores (Long, I965a, pp. II4-I25).

\section{Morton (I8I9-I 868)}

Embora Crawford Long tenha sido o primeiro médico a usar a anestesia geral pelo éter e Horace Wells o primeiro dentista a fazer extração de dente sem dor, com a inalação de óxido nitroso, cabe ao dentista William Thomas Green Morton a glória de haver introduzido a anestesia geral em cirurgia. Long não divulgou o método e o abandonou, temendo consequências desagradáveis. Wells fracassou em uma demonstração pública, abandonou a profissão de dentista e, após a divulgação do sucesso de Morton, cometeu suicídio aos 33 anos de idade.

Morton, depois de utilizar a inalação de éter em extrações dentárias teve a ideia de estender o método à cirurgia e convenceu o cirurgião John Warren, do General Massachusetts Hospital, de Boston, a permitir que ele fizesse uma demonstração. Idealizou e construiu um inalador para regular a quantidade de éter a ser administrada e realizou a primeira demonstração bem sucedida no dia 16 de outubro de I 846 . Aquilo que um grande cirurgião francês, Velpeau, considerava uma quimera tornou-se realidade. Ao término da operação, Warren, percebendo o grande significado daquela descoberta, proferiu as seguintes palavras: "Daqui a muitos séculos os estudantes virão a este hospital para conhecer o local onde se demonstrou, pela primeira vez, a mais gloriosa descoberta da ciência". A sala de cirurgia foi conservada intacta como patrimônio histórico.

Com o sucesso alcançado, Morton sofreu uma campanha de descrédito capitaneada por seu ex-professor de Química, Charles Thomas Jackson, que reivindicava para si a prioridade da descoberta. Houve muitas reações contra a anestesia, inclusive de ordem religiosa, porém insuficientes para deter sua aceitação. Em dezembro do mesmo ano a anestesia pelo éter já era usada na Inglaterra e na França e, no ano seguinte, na Alemanha, na Rússia e em outros países, inclusive no Brasil. 
Morton morreu pobre, de morte súbita, em uma via pública de Nova York, aos 49 anos de idade. A denominação de anestesia foi proposta pelo médico e poeta norte-americano Oliver Wendel Holmes. A palavra já existia em grego e fora usada por Dioscórides (de an, privado de + aisthesis, sensibilidade) (Fülop-Miller, I95 I, pp. I36-163).

\section{Lister (I 827-I9I 2)}

Joseph Lister nasceu em Londres e foi professor de cirurgia em Glasgow e Edimburgo. Em Glasgow preocupava-se com a supuração das feridas operatórias e com a alta mortalidade das amputações, que chegava a $45 \%$. Ao tomar conhecimento dos estudos de Pasteur que demonstravam que a fermentação era causada por micro-organismos, teve a intuição de que a supuração e a gangrena nos hospitais fossem igualmente causadas por micróbios existentes no ar. Ocorreu-lhe usar um antisséptico nas fraturas expostas e optou pelo ácido carbólico (ácido fênico) de reconhecida ação desinfetante. Seu método consistia em introduzir mechas de pano embebidas em ácido carbólico nas feridas e recobrir estas para evitar contato com o ar atmosférico. Em I 867 publicou no Lancet sua experiência com os primeiros onze casos de fraturas expostas assim tratados, sem nenhum caso de gangrena ou supuração.

Os cirurgiões ingleses se opuseram às ideias de Lister. Seu método, entretanto, difundiu-se no continente europeu e foi adotado com entusiasmo na Alemanha e na Áustria. Em I 869 Lister transferiu-se para Edimburgo onde permaneceu durante nove anos como professor de clínica cirúrgica. Tendo observado que a infecção pós-operatória localizava-se de preferência nas suturas, passou a mergulhar o categute e outros fios de sutura no ácido carbólico antes de usá-los. Era costume o cirurgião exteriorizar as pontas do categute para fora da ferida cirúrgica para drenar o pus que se formava e que era considerado normal. Lister foi o primeiro a cortar o categute rente ao nó, sem complicações. Por último, Lister passou a utilizar um spray de ácido carbólico no campo operatório durante o ato cirúrgico. Em I 877, com cinquenta anos, retornou a Londres como professor de clínica cirúrgica.

Aos poucos, os ingleses reconheceram o mérito de Lister e o cumularam de homenagens e honrarias. As descobertas da anestesia geral e da antissep- 
sia, posteriormente substituída pela assepsia, tornaram possível a moderna cirurgia (Thorwald, s.d., pp. 247-263).

\section{Pasteur (I 822-I 895)}

Louis Pasteur nasceu em Dôle, na França. Não era médico e sim químico. Suas primeiras pesquisas referem-se ao ácido tartárico. Aos 22 anos foi professor de física em Dijon e Estrasburgo e aos 32, professor e diretor da Faculdade de Ciências de Lille, onde havia usinas de produção de álcool. Em Lille interessou-se pela fermentação alcoólica e a fermentação do leite.

Em I 857 foi nomeado diretor científico da Escola Normal de Paris, onde continuou seus estudos sobre fermentação. Verificou que a fermentação se deve à ação de micro-organismos existentes no ar atmosférico. Demonstrou experimentalmente que a geração espontânea era um mito que devia ser abandonado. Em I 864 foi solicitado a estudar a fermentação que ocorria no vinho e que estava arruinando a indústria vinícola na França. Descobriu nessa ocasião que o aquecimento do vinho à temperatura entre $50^{\circ} \mathrm{C} \mathrm{e} 60^{\circ} \mathrm{C}$ destruía os germes sem alterar a qualidade do vinho. Este método foi chamado de "pasteurização" e utilizado também para a cerveja e o leite. Solicitado a estudar a pebrina, uma doença do bicho-de-seda, constatou que a mesma era produzida por germes que infectavam os ovos e que poderia ser evitada pela seleção de ovos não contaminados e a destruição dos demais.

Em I 877 voltou sua atenção para o antraz, que dizimava os rebanhos de carneiros, e para o cólera aviário. Isolou os micróbios responsáveis e verificou que o do cólera perdia virulência em culturas velhas, o mesmo ocorrendo com o do antraz quando aquecido a $42^{\circ} \mathrm{C}$. Descobriu que a inoculação do micróbio com virulência atenuada protegia o animal da doença e deu ao método a denominação de "vacinação", em homenagem a Jenner.

Sua última e notável contribuição à ciência e à medicina foi a descoberta do tratamento da hidrofobia. As descobertas de Pasteur, além de sua natureza científica, tiveram imediata aplicação prática, que redundou em real benefício para a humanidade. A motivação patriótica de seus estudos proporcionaram ainda maior riqueza à França.

Pasteur foi glorificado em vida e apesar de não ser médico foi admitido na Academia de Medicina da França. Uma subscrição internacional, que teve 
a participação de d. Pedro II, Imperador do Brasil, levantou a quantia de 2500000 francos para construção do Instituto Pasteur de Paris, inaugurado em I 888. Já doente e hemiplégico, Pasteur pouco utilizou os laboratórios do novo Instituto, vindo a falecer em I 895 (Oliveira, I98 I, pp. 394-399).

\section{Koch (I847-I910)}

Robert Koch, natural de Hannover, na Alemanha, foi um dos fundadores da bacteriologia. Graduou-se em medicina em I 866 na Universidade de Götingen e, a partir de I 870, foi médico distrital em Hollestein. Discípulo de Henle, interessava-se pela microscopia. Montou um pequeno laboratório em sua própria residência, onde desenvolveu novos métodos de cultura e de coloração das bactérias. Em I 876 obteve culturas puras do bacilo do antraz e descobriu o fenômeno da formação de esporos, que poderiam reverter-se à forma infectante de bacilo. Em I 878 publicou uma monografia sobre a infecção das feridas, com a descrição de várias espécies diferentes de bactérias. Em I 880 foi trabalhar no Instituto Imperial de Saúde em Berlim, onde passou a dispor de um laboratório bem equipado e de dois assistentes.

Em I 882 descobriu o bacilo da tuberculose, o que lhe valeu o respeito e a admiração de toda a comunidade científica internacional. Na publicação sobre esta descoberta, Koch estabeleceu os postulados, que se tornaram clássicos, para identificação do agente etiológico das doenças infecciosas: I) o micro-organismo deve estar presente em todos os casos da doença; 2) deve ser isolado em culturas puras; 3 ) a inoculação da cultura em animais suscetíveis deve reproduzir a doença; 4) deve ser encontrado nos animais assim infectados e crescer em culturas puras.

Em I 883 chefiou a Comissão alemã enviada ao Egito e à Índia para estudo do cólera, que grassava naqueles países. $\mathrm{Na}$ Índia descobriu o vibrião do cólera e comprovou sua transmissão pela água, alimentos e vestuário. Em I 890, Koch obteve a tuberculina das culturas do bacilo da tuberculose e supôs que a mesma pudesse ser usada no tratamento da tuberculose. A experiência demonstrou sua ineficácia como remédio, porém útil para o diagnóstico. Em I89I Koch foi indicado para diretor do recém-fundado Instituto Imperial de Saúde de Berlim, cargo em que permaneceu até 1904. A pedido do governo inglês dirigiu-se à África do 
Sul, onde realizou estudos sobre a doença do sono, malária, peste bubônica e endemias de interesse veterinário.

Em 1905 recebeu o prêmio Nobel de Fisiologia e Medicina. Tornou-se famoso em todo o mundo e recebeu inúmeras láureas e títulos honoríficos. Faleceu em I9 I0, aos 67 anos. Depois dele e graças ao seu trabalho pioneiro, a bacteriologia teve um grande desenvolvimento, com a identificação dos agentes etiológicos de várias enfermidades como a febre tifoide, pneumonia, erisipela, difteria, tétano, meningite, peste e outras (Major, op. cit., pp. 636-842).

\section{Roentgen (I 845-I923)}

Em novembro de I 895, o físico alemão Wilhelm Conrad Roentgen descobriu em seu laboratório de física da Universidade Würzburg um novo de tipo de radiação, a que chamou de raios-X por desconhecer a sua natureza. Ao passar uma corrente elétrica por uma ampola de Crooks recoberta por papel negro, em ambiente também escuro, notou luminescência em uma placa de platinocianeto de bário que se encontrava sobre a mesa. Verificou que essa radiação tinha o poder de atravessar o papel, a madeira e outros objetos, e de impressionar um filme fotográfico. Colocando a mão de sua esposa sobre o filme, obteve com os raios-X uma fotografia dos ossos da mão com o anel no dedo anular. Convencido da importância de sua descoberta, apresentou à Sociedade de Física Médica de Würzburg, para publicação, uma nota prévia com o título "Sobre uma Nova Espécie de Raios".

Em 23 de janeiro de I 896 fez uma demonstração perante àquela sociedade, fotografando a mão do professor de anatomia da Universidade, Albert von Kolliker. Kolliker propôs o nome de raios Roentgen para os raios-X. A notícia espalhou-se pelo mundo, prevendo-se a aplicação imediata dos raios-X em medicina. Roentgen não quis tirar patente de sua descoberta $\mathrm{e}$ respondeu a propostas nesse sentido com as seguintes palavras: "De acordo com a tradição dos professores universitários alemães, sou de opinião que as descobertas e invenções se destinam a servir à humanidade e não devem ter qualquer exclusividade, nem proteção de patentes, licenças ou contratos, nem devem ser controlados por qualquer grupo". Com esse propósito, Roentgen deixava livre o caminho para que as empresas industriais construíssem e aperfeiçoassem aparelhos de raios-X. Já em I 897 foram os 
mesmos utilizados em cirurgia militar, na guerra da Grécia com a Turquia e na guerra dos Canudos, no Brasil.

Roentgen foi o primeiro a receber o prêmio Nobel de Física em I90 I. A partir de então Roentgen sofreu uma campanha de descrédito por parte de alguns físicos da época quanto a sua prioridade na descoberta, o que muito o amargurou, apesar das muitas homenagens e honrarias que recebeu. Faleceu em Munique, em I923, aos 78 anos. A descoberta dos raios-X assinala o início da era tecnológica da medicina (Santos, I995, pp. 37-II3).

\section{Século Xx}

\section{Landsteiner (I 868-1943)}

A partir do século XVII foram feitas várias tentativas de transfusão de sangue, inicialmente de animal para o homem e, a seguir, de uma pessoa a outra, braço a braço. Raramente a transfusão era bem-sucedida; na maioria das vezes provocava reações no receptor ou mesmo a sua morte. Os riscos eram tão grandes que a transfusão de sangue foi proibida ou abandonada.

Coube a Karl Landsteiner esclarecer a razão das desastrosas consequências da transfusão de sangue, tornando-a um método terapêutico seguro e rotineiro. Landsteiner era austríaco. Graduou-se em medicina na Universidade de Viena em I891, aos 23 anos. Dedicou-se à pesquisa em lugar da prática médica. Interessou-se particularmente pela bioquímica e pela imunologia. Como professor-assistente da Universidade de Viena, aos 32 anos, descobriu que havia no homem grupos sanguíneos incompatíveis entre si. Usando a técnica da aglutinação descreveu inicialmente três grupos, a que chamou $A, B$ e $C$ e divulgou sua descoberta em I90 I em um artigo de apenas três páginas. $\mathrm{O}$ quarto grupo foi acrescentado um ano depois por seus colaboradores Alfred von Decastello e Adriano Sturli. Em 1909 Emil von Dungern e Ludwick Hirsfeld deram a este grupo a denominação de $A B$ e mudaram o nome do terceiro grupo para O. Em I92 I Landsteiner foi convidado a trabalhar no Instituto Rockefeller, em Nova York, e transferiu-se para os Estados Unidos, naturalizando-se cidadão norte-americano.

Em I930 recebeu o prêmio Nobel de Fisiologia e Medicina. Landsteiner era um pesquisador infatigável e de grande criatividade. Ao deixar a Áustria 
já havia publicado I7I trabalhos sobre os mais diversos temas ligados à hematologia, imunologia, bioquímica, patologia e bacteriologia. Em I940, aos 72 anos, fez outra descoberta importante juntamente com seus colaboradores Alexander Wiener e Philip Levi - a do fator Rh, que veio esclarecer a etiologia da eritroblastose fetal e evitar a sensibilização do receptor (Shoemaker, I99I, pp. 317-323).

\section{Fleming (I88I-I955)}

Alexander Fleming vinha já há algum tempo pesquisando substâncias capazes de matar ou impedir o crescimento de bactérias nas feridas infectadas. Essa preocupação se justificava pela experiência adquirida na Primeira Grande Guerra (I9I4-I9I8), na qual muitos combatentes morreram em consequência da infecção em ferimentos profundos. Fleming fora um aluno brilhante no curso médico. Após sua graduação, dedicou-se à bacteriologia, como assistente de Almroth Wright no St. Mary's Hospital, de Londres. Foram muitas as suas pesquisas, porém a descoberta da penicilina ofuscou as demais.

Em I92I Fleming descobrira uma substância antibacteriana existente nas secreções como a lágrima, muco nasal e saliva, a qual dera o nome de lisozima. Em 1928 Fleming desenvolvia pesquisas sobre estafilococos, quando descobriu a penicilina. A descoberta da penicilina deu-se graças ao acaso e ao espírito de observação de Fleming, confirmando a sentença de Pasteur de que o acaso só favorece as mentes preparadas. A descoberta de Fleming não despertou inicialmente maior interesse e não houve a preocupação em utilizá-la para fins terapêuticos em casos de infecção humana até a eclosão da Segunda Guerra Mundial, em I939.

Em I940, Sir Howard Florey e Ernst Chain, de Oxford, retomaram as pesquisas de Fleming e conseguiram produzir penicilina com fins terapêuticos em escala industrial, inaugurando uma nova era para a medicina - a era dos antibióticos. Em I945, Fleming, Florey e Chain receberam conjuntamente o prêmio Nobel de Fisiologia e Medicina (Rosenblum, I99I, pp. 5 I $7-525)$. 
Crick, físico inglês, interessou-se pela biologia e fez seu doutorado em Cambridge, na Inglaterra, sobre estrutura das proteínas, utilizando cristalografia e difração aos raios-X. Em I95 I associou-se a um jovem americano, James Watson, que havia sido admitido no mesmo laboratório como pós-graduando em genética e bioquímica. Ambos se propuseram a realizar estudos sobre a estrutura tridimensional do DNA, cuja composição já era conhecida. Sabia-se que o DNA era uma macromolécula alongada, formada de nucleotídeos contendo um açúcar (deoxirribose), fosfato e quatro bases (adenina, citosina, guanina e timina). Sabia-se também que a quantidade de adenina é exatamente igual a de timina e a quantidade de citosina a mesma de guanina.

$\mathrm{Na}$ mesma época, no King's College, de Londres, Maurice Wilkins e Rosalind Franklin desenvolviam pesquisas similares. Ao contrário de Crick e Watson, Wilkins e Franklin trabalhavam individualmente e não em colaboração. Rosalind Franklin era especialista em cristalografia e desenvolveu técnica que permitiu usar a difração aos raios-X para obter fotografias da molécula do DNA. Graças às pesquisas de Wilkins, Franklin e outros investigadores tornou-se evidente que o açúcar (ribose) ocupava a parte externa da molécula, enquanto as bases ocupavam a parte interna. Por outro lado, as fotografias obtidas por Franklin, especialmente uma que ficou famosa e conhecida pelo número $5 \mathrm{I}$, indicavam que a molécula de DNA tinha a forma helicoidal.

Depois de rever todos os dados disponíveis na literatura e tomar conhecimento dos achados de Franklin e Wilkins, Crick e Watson puseram-se a construir modelos que fossem a réplica da molécula do DNA. Após várias tentativas, concluíram que o modelo que satisfazia todos os requisitos era o da dupla hélice, antiparalela, em forma de escada em espiral, na qual os degraus seriam formados por pares de bases, estando a adenina sempre ligada à timina e a citosina à guanina. Cada base se manteria unida a seu par por um átomo de hidrogênio. Convencidos de que haviam descoberto a estrutura do DNA encaminharam a comunicação à revista Nature, que publicou o artigo em 25 de abril de I953. O mesmo número da revista publicou também uma comunicação de Rosalind Franklin e outra de Maurice Wilkins, com os resultados de suas pesquisas. 
Crick, Watson e Wilkins receberam o prêmio Nobel de I962. Rosalind Franklin não foi incluída por haver falecido de câncer em I958, aos 38 anos. Difícil dizer a quem pertence o maior mérito nessa descoberta. Crick e Watson foram os mais distinguidos, porém o brilho do seu trabalho foi de certo modo apagado quando se soube que, para a construção do modelo, haviam utilizado dados não publicados e fotografias feitas por Franklin e Wilkins, sem autorização e conhecimento destes, e sem a necessária referência (Hollar Jr., I991, pp. 839-847).

\section{Rosalyn Yallow (I92I-)}

Numa época em que o curso de física era frequentado somente por alunos do sexo masculino, Rosalyn Yallow foi a primeira mulher a obter $\mathrm{PhD}$ em Física Nuclear, em I945. Em I 950 associou-se ao médico Salomon Berson, do Veterans Hospital, de Nova York, e juntos iniciaram um amplo projeto de estudos sobre o emprego de radioisótopos em medicina. Os conhecimentos de matemática e física de Yallow e os de medicina de Berson se completavam para o programa que tinham em mente. A parceria entre eles só foi interrompida em I972, com a morte de Berson.

Iniciaram as investigações com estudos sobre o diabetes do adulto. Injetaram insulina marcada com iodo radioativo em indivíduos normais e em pacientes diabéticos e verificaram que, ao contrário do que esperavam, a radioatividade permanecia por mais tempo no organismo dos diabéticos do que nos indivíduos normais. Atribuíram o fato à formação de anticorpos anti-insulina. Para a quantificação desses anticorpos, os métodos de dosagem disponíveis eram inadequados. Yallow desenvolveu, então, um método extremamente sensível usando radioisótopos, a que denominou de "radioimunoensaio" (RIA).

Além da sua importância no estudo do diabetes, o novo método, por sua alta sensibilidade, proporcionou um avanço extraordinário da biologia, de um modo geral, e da endocrinologia, em particular. Mostrou-se capaz de detectar concentrações de proteínas um milhão de vezes menor do que as menores concentrações que se poderiam dosar pelos métodos convencionais. Em I963, Yallow e Berson empregaram o radioimuniensaio para dosar vários hormônios. Em 1970, Yallow passou a chefiar o Serviço de Medicina 
Nuclear do Veterans Hospital e, após a morte de Berson em I972, prosseguiu nas pesquisas programadas e dosou a colecistocinina. A importância do método se refletiu de imediato no campo da imunologia na dosagem de antígenos e anticorpos.

Yallow recebeu diversos prêmios, títulos e homenagens, culminando com o prêmio Nobel em I977. Ao receber o prêmio Nobel reverenciou a memória de Berson, a quem devia o sucesso de sua carreira. O método do radioimunoensaio foi substituído posteriormente pelo imunoenzimático (Elisa), baseado nos mesmos princípios (Howes, I99I, pp. I 283-I 29I).

\section{Basil Hirschowitz (1928-)}

A endoscopia passou por quatro fases: a das válvulas e espéculos, na Antiguidade; a dos endoscópios rígidos, no século XIX e início do século Xx; a dos endoscópios semiflexíveis, de 1932 a I957, e a dos endoscópios flexíveis, a partir desta data. Os endoscópios rígidos eram desconfortáveis, de maior risco para os pacientes e de aplicação limitada. A partir de I932, Rudolf Schindler introduziu o gastroscópio semiflexível, que permitia o exame parcial do estômago. A transmissão da imagem através do segmento distal encurvado do aparelho se fazia por sistema de pequenos espelhos incrustados no interior do tubo. A grande revolução, que transformou a endoscopia em um método de exame seguro e eficiente, ocorreu em I957, com o emprego da fibra óptica para iluminação e transmissão da imagem.

A ideia de construir um endoscópio com fibra óptica se deve a Basil Hirschowitz, um pós-graduando sul-africano que estagiava em Ann Arbor, nos Estados Unidos. Hirschowitz associou-se ao físico Larrey Curtiss e trabalharam juntos de I954 a I957 na construção do aparelho. A dificuldade maior por eles encontrada se devia à dispersão da luz no feixe de fibras colocadas no interior do tubo, ocasionando deformidade e baixa resolução da imagem. Em 1956, Curtiss resolveu o problema, fabricando fibras ópticas revestidas por outra capa de vidro de densidade diferente, que impedia a dispersão da luz. Com essa modificação obtiveram a transmissão da imagem com boa qualidade e sem deformação.

Em I 6 de março de 1957, Hirschowitz e Curtiss apresentaram o protótipo do aparelho e fizeram uma demonstração no congresso de endoscopistas 
reunido em Colorado Springs, ressaltando as vantagens do aparelho em relação ao modelo semiflexível então em uso. A inovação não despertou entusiasmo entre os presentes e foi recebida com ceticismo.

Hirschowitz procurou interessar as indústrias de instrumentos ópticos e somente a American Cystoscope Makers Inc. demonstrou interesse em sua fabricação. Após três anos, em outubro de I960, finalmente a ACMI lançou no mercado o gastroscópio de fibras ópticas. Sucessivos aperfeiçoamentos introduzidos posteriormente por outros fabricantes fizeram do gastroscópio de Hirschowitz o principal instrumento no diagnóstico das afecções do esôfago, estômago e duodeno. Dentro dos mesmos princípios foram construídos a seguir outros tipos de endoscópios, como o colonoscópio e o broncoscópio.

$\mathrm{Na}$ década de 1980 , a fibroendoscopia foi substituída pela videoendoscopia. Hirschowitz, apesar de não ter sido contemplado com o prêmio Nobel, foi, sem dúvida, um dos construtores da moderna medicina (Edmonson, I99I, pp. 827-856).

\section{Oswaldo Cruz (1872-19I7)}

Dentre os grandes vultos da medicina brasileira que contribuíram para a moderna medicina, nossa escolha recaiu em Oswaldo Cruz. Foi ele um gigante que estava destinado a mostrar ao mundo a importância do saneamento básico e da vacinação preventiva no combate às epidemias.

No início do século xx, o Rio de Janeiro, capital do Brasil, era uma cidade imunda, doentia, infestada de ratos, de mosquitos, onde grassavam as piores doenças epidêmicas da época: febre amarela, peste bubônica, cólera e varíola. Os navios procedentes da Europa recusavam-se a fazer escala no Rio de Janeiro e iam direto a Buenos Aires. Rodrigues Alves, eleito presidente da República em 1902, diante da situação calamitosa do Rio de Janeiro, nomeou prefeito da cidade o engenheiro Francisco Pereira Passos e diretor do Departamento Nacional de Saúde Pública o médico Oswaldo Cruz, que lhe fora apresentado como o médico sanitarista mais indicado para o cargo, ambos com amplos poderes e autonomia de ação.

Oswaldo Gonçalves Cruz era natural de Paraitinga, estado de São Paulo. Concluiu o curso médico no Rio de Janeiro e, após sua graduação, estagiou no Instituto Pasteur de Paris, onde se especializou em microbiologia e saúde pública. 
Enquanto Pereira Passos promovia a reurbanização da cidade, Oswaldo Cruz atacava as doenças epidêmicas. Para o combate à febre amarela, criou a "Brigada Mata-mosquitos", que tinha a missão de vistoriar todas as residências e eliminar os focos de reprodução do Aedes egypti. Os mata-mosquitos iam acompanhados de policiais, pois muitos moradores se recusavam a permitir a inspeção. Para o combate à peste bubônica fazia-se mister a desratização da cidade. Com esse fim, Oswaldo Cruz apelou para o auxílio da população, orientando-a sobre a maneira de envenenar os ratos e pagando cem réis por rato vivo ou morto. Houve quem criasse ratos em casa para vender às autoridades sanitárias. A prevenção do cólera foi alcançada com as obras de saneamento básico e medidas higiênicas.

Restava a varíola. Para extinguí-la só havia um meio - vacinação obrigatória -, visto que parte da população recusava a vacinar-se. A lei da vacinação obrigatória desencadeou uma campanha contra Oswaldo Cruz. A população, médicos homeopatas e muitos políticos de projeção colocaram-se em oposição à lei, que foi taxada de inconstitucional, pois feria liberdade individual. Em novembro de 1904 Rodrigues Alves foi pressionado a demitir Oswaldo Cruz, e se recusou a fazê-lo, o que provocou um movimento armado, com a participação de militares, para depor o presidente da República, episódio que ficou conhecido como "Revolta da Vacina". Revogada a lei, a população foi, aos poucos, aderindo à vacinação ao constatar a sua eficácia em prevenir a doença. A cidade tomou novo aspecto com a remodelação urbana, a higienização e o desaparecimento gradativo das doenças epidêmicas. $\mathrm{O}$ trabalho de Oswaldo Cruz foi reconhecido internacionalmente.

Após o sucesso alcançado com o saneamento do Rio de Janeiro, Oswaldo Cruz lançou-se à sua maior empresa, que foi a da institucionalização da pesquisa médica científica no Brasil, com a fundação do Instituto de Manguinhos, hoje Instituto Oswaldo Cruz. Oswaldo Cruz faleceu em I9 I7, na cidade de Petrópolis, com 45 anos incompletos (Bacellar, I963, pp. I3 I-I 56).

Vimos, assim, em voo de pássaro, a evolução da medicina desde Hipócrates até os nossos dias e quem foram os construtores das pilastras de sustentação dessa evolução. Devemos considerar que as descobertas em medicina, como em todas as ciências, não são fruto unicamente de mentes superdotadas, mas de um contexto histórico que condiciona o ambiente, 
as circunstâncias e os meios para sua eclosão. São como os frutos de uma árvore, que só aparecem quando esta fixa suas raízes no solo e desenvolve o tronco, que irá conduzir a seiva até os menores ramos.

\section{Referências Bibliográficas}

Bacellar, R. C. Brazil's Contribution to Tropical Medicine and Malaria. Rio de Janeiro, Gráfica Olímpica Editora, I963.

Castiglioni, A. História da Medicina. São Paulo, Cia. Editora Nacional, 1947.

Edmonson, I. M. "History of the Instruments for Gastrointestinal Endoscopy", Gastrointestinal Endoscopy, 37 (2), supl., pp. 827-856, I99I.

Fülop-Miller, R. O Triunfo sobre a Dor: História da Anestesia. São Paulo, José Olympio, I95 I.

Harvey, W. Estudo Anatômico do Movimento do Coração e do Sangue nos Animais. São Paulo, Editora Unifesp, 2009.

Hollar JR., D. W. “Francis Crick-I962”. In Magill, F. N. The Nobel Prize Winners. Pasadena, Salem Press, I99I.

Howes, R. H. "Rosalyn A. Yalow-r977”. In Magill, F. N. The Nobel Prize Winners. Physiology or Medicine. Pasadena, Salem Press, I99I.

Long, E. R. "Virchow and the Cellular Pathology". A History of Pathology. New York, Dover Publications, I965a. "Morgagni and the Eighteenth Century". A History of Pathology. New York, Dover Publications, I965b.

Major, R. H. A History of Medicine. Oxford, Blackwell Scientific Publications, I954.

Oliveira, A. B. A Evolução da Medicina até o Início do Século xx. São Paulo, Livraria Pioneira Editora, I98I.

Porter, R. The Biographical Dictionary of Scientists. New York, Oxford University Press, I995.

Rosenblum, J. “Sir Alexander Fleming-r945”. In Magill, F. N. The Nobel Prize Winners. Physiology or Medicine. Pasadena, Salem Press, I99I.

Santos, I. B. Wilhelm Conrad Roentgen. São Paulo, Colégio Brasileiro de Radiologia, I 995. Shoemaker, J. P. “Karl Landsteiner-I930”. In Magill, F. N. The Nobel Prize Winners.

Physiology or Medicine. Pasadena, Salem Press, I99I.

TARChis, J.Father of ModernAnatomy-Andreas Vesalius. New York, The Dias Press, I 950. Thorwald, J. O Século dos Cirurgiões. São Paulo, Boa Leitura Editora, s.d. 